\title{
A review on Dickeya solani, a new pathogenic bacterium causing loss in potato yield in Europe
}

\author{
Matgorzata Golanowska, Ewa ŁoJKowsKa* \\ Department of Biotechnology, University of Gdańsk, Gdańsk, Poland
}

\begin{abstract}
A pectinolytic bacteria of the genera Dickeya and a Pectobacterium (formerly, pectinolytic Erwinia) are the two causal agents of blackleg and soft rot diseases of potato and soft rot of other economically important vegetables and ornamental plants. Dickeya and Pectobacterium are in a group of top ten bacterial pathogens causing great damage and important economic losses of different crops. Potato yield reduction caused by Dickeya species has significantly increased in recent years. These bacteria have been frequently and increasingly isolated from diseased potato plants in Poland, Finland, France, the Netherlands, Switzerland, and other European countries, as well as Israel. Until the end of the last century, the only species of Dickeya genus that had caused disease symptoms on potato plants in Europe was Dickeya dianthicola. According to our current knowledge, since the beginning of the $21^{\text {st }}$ century, bacteria showing characteristics typical of Dickeya solani have been isolated from potato in Europe. In Poland, they were isolated for the first time in 2005. Yet, it was only in 2014 that the $D$. solanispecies was established. Recent results indicate that $D$. solani strains can efficiently infect potato and cause disease symptoms in temperate climate. $D$. solani strains are considered to be more aggressive than other blackleg-causing bacteria. There is a need for intense research on the pathogenicity of $D$. solani, not only because it is fast spreading across Europe or because of its better adaptation to various climatic conditions, but also because of the lack of efficient means to control the pectinolytic bacteria during plant vegetation, transport of the potato tubers, and their storage.
\end{abstract}

Key words: blackleg, soft rot, pathogenicity, pectinolytic bacteria

\section{Importance of the research on Dickeya spp.}

Potato (Solanum tuberosum L.) is among the top ten commodities produced in the world. In 2013, it was sixth according to FAOSTAT, the statistics division of Food and Agriculture organization of United States (http:// faostat3.fao.org/home/E). The first reported disease caused by Erwinia chrysanthemi (most probably belonging to the species Dickeya dianthicola) on potato in Europe occurred over 40 years ago (Toth et al., 2011).

In most European countries, losses attributable to the bacteria from the species Dickeya and Pectobacterium belonging to the Soft-rot Enterobacteriaceae (SRE) family have remained generally low. But in recent years, potato yield losses caused by Dickeya spp. have increased significantly in a number of European countries and in Israel, a major importer of European potato seed tu- bers (Fig. 1). Potato yield reduction caused by Dickeya spp. was evaluated as about $30 \%$ in the Netherlands and 20 to $25 \%$ in Israel. Up to $25 \%$ of the potato blackleg incidences in the Netherlands, Belgium, and France have been attributed to infections caused by Dickeya spp. (Toth et al., 2011). This may be associated with the emergence of a new Dickeya species - D. solani - that could have most likely spread by trade in seed tubers, and potentially in future years, could have a larger impact as a consequence of climate change (Toth et al., 2011; van der Wolf et al., 2014b). Until 2000, Pectobacterium atrosepticum and $D$. dianthicola were considered to be responsible for the majority of potato blackleg infections in Europe (Perombelon and Kelman, 1980; Perombelon, 2002). Recent results, obtained in different European countries, indicate that a new group of Dic-

\footnotetext{
* Corresponding author: Department of Biotechnology, University of Gdańsk, Abrahama str. 58, 80-307 Gdańsk, Poland; e-mail: ewa.lojkowska@biotech.ug.edu.pl
} 


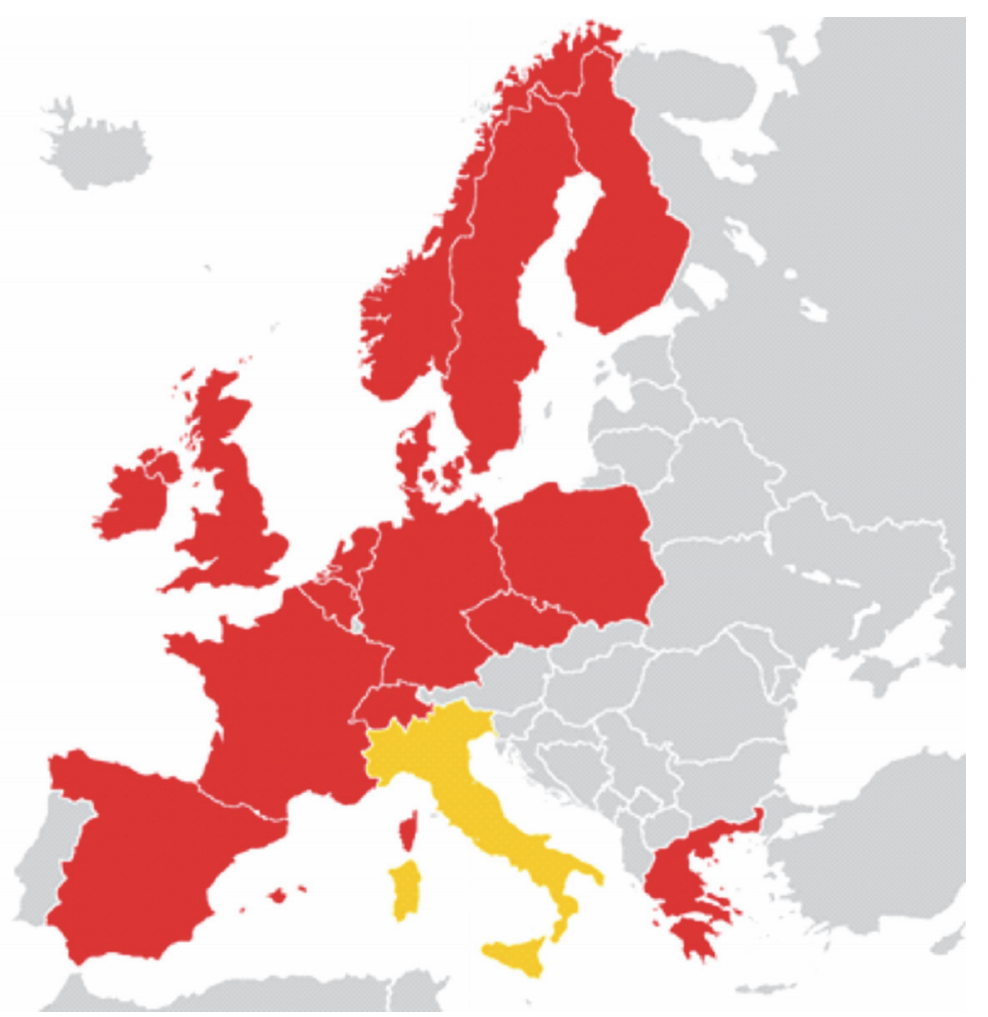

Fig. 1. The distribution of Dickeya solani on potato in Europe. On the basis of EUPHRESCO Report 2013 and Potrykus et al. 2016. The red color represents Dickeya solani, the yellow color represents Dickeya dianthicola

keya spp. strains can efficiently infect potato plants and cause disease symptoms in temperate climate. This new group of Dickeya spp. strains - D. solani was already described in 2009 (Sławiak et al., 2009b), but established as a new species only in 2014 (van der Wolf et al., 2014b). D. solani was first detected in Poland in 2005 (Sławiak et al., 2009a), but later on it was increasingly found on Polish potato seed plantations (Łojkowska et al., 2010; Potrykus et al., 2016).

All $D$. solani strains shared similar results in biochemical assays, identical molecular profiles based on rep-PCR and identical sequences of $16 \mathrm{~S}$ rDNA and some of the housekeeping genes (e.g., $d n a X, r e c A, g y R r p o S$ ). Current studies indicate that all strains of $D$. solani studied so far show a high level of similarities in their characteristics, which may suggest a common origin, possibly a single introduction in the potato ecosystem (Sławiak et al., 2009b; Wolf et al., 2014b; Potrykus et al., 2016).

In general, Dickeya spp. are high-temperature pathogens, which are believed to play a major role in blackleg epidemiology in tropical and subtropical regions. In $\mathrm{Eu}-$ rope, over the past 10 years, the incidence of infections of seed potato by the bacteria of genus Dickeya has increased relatively, compared to those from genus Pectobacterium (Laurila et al., 2008; Łojkowska et al., 2010; Toth et al., 2011; Potrykus et al., 2016).

$D$. solani strains are considered to be more aggressive than other blackleg-causing bacteria. The analysis presented here suggests that they need lower optimal temperatures for disease development as well as lower inoculum levels for infection threshold (Toth et al., 2011; Czajkowski et al., 2012). They seem to have a greater ability to colonize potato plant roots and to spread through the plants' vascular system (Czajkowski et al., 2010). In 3 years of field studies in the Netherlands with $D$. dianthicola and $D$. solani, disease severity varied annually and between species. Czajkowski and coworkers (2012) concluded that $D$. solani possesses features that allow more efficient plant colonization than $D$. dianthicola.

There is less information on the existence of $D$. solani outside European countries and Israel. There is no evidence of the presence of $D$. solani in the Americas or Australia. But $D$. solani on hyacinth bulbs has been reported to be found in China (Chen et al., 2015) and in 
Malaysian waterfalls (GeneBank accession number JSXD 00000000.1, Win-Si Tan, University of Malaysia). D. solani, however, has not only been isolated from symptomatic potato plants, but also from the potato rhizosphere, as a potential biocontrol agent against Rhizoctonia solani, Verticillium dahliae, and Phytophthora infestans in the field study of genetically modified potatoes in Germany (Weinert et al., 2010). These strains possess identical rep-PCR and RFLP-PFGE profile as the type strain of $D$. solani IPO2222 and strains isolated in Poland in 2005 and 2009 (IFB0099 and IFB0158). However, they indicate a much lower ability to macerate potato tissue and a lower ability to produce plant cell wall degrading enzymes (PCWDE), (Potrykus et al., 2014a).

Apart from the availability of $7 \mathrm{D}$. solani genomes, the genetics of $D$. solani is poorly understood in comparison to what is available and known about $D$. dadantii (a species closely related to $D$. solani). The genomic analyzes on $D$. solani strains performed by Garlant and coworkers (2013) and Pedron and coworkers (2014) have revealed open reading frames (ORF) possibly involved in virulence and the production of toxic compounds. They were annotated as polyketide synthases (PKS), non-ribosomal peptide synthetases (NRPS), and amino acid adenylation domain proteins, suggesting that they encode proteins that may be involved in the production of such metabolites as antibiotics and toxins. Pedron and coworkers (2014) pointed out a higher variability in proteins transported via Type 5 and T6 secretion systems (5SS/T6SS) in D. solani 3337 than in D. dadantii 3937.

The main information about virulence and regulation is acquired from the knowledge about closely related and mostly studied species, $D$. dadantii 3937 . This strain's metabolism and regulation of pectinolysis have been studied for about 40 years (Kotoujanski et al., 1982). Many tools have been developed for $D$. dadantii 3937, so that the vast features and pathogenicity strategy of $D$. solani can be better understood. The knowledge about regulation of the expression of genes encoding virulence factors like PCWDE in D. solani has been obtained in our laboratory (Potrykus et al., 2014a).

Nowadays, by means of comparative and functional genomics, researchers can improve the understanding of adaptation modes to different ecological niches and the genes involved in $D$. solani pathogenicity (Toth et al., 2006; Pritchard et al., 2016). It is worth insisting that there is a need for intense research on the mole- cular regulation of the $D$. solani pathogenicity not only because of its fast spreading nature across Europe or its better adaptation to various climatic conditions (not only temperate climates such as in Poland or cold climates in Finland, but also hot climates such as in Israel), but also because of the lack of efficient means to control the pectinolytic bacteria during the vegetation and storage (Toth et al., 2011; Czajkowski et al., 2011).

\section{The enemy - Soft Rot Enterobacteriaceae - D. solani}

Bacteria from genera Dickeya and Pectobacterium form a group of pectinolytic plant pathogenic bacteria. Based on their economic and scientific impact, these species have been included among the 10 most important bacterial plant pathogens (Mansfield et al., 2012). The most recent taxonomy of SRE states that these bacteria belong to the kingdom of Bacteria, phylum Proteobacteria, class Gammaproteobacteria, order Enterobacteriales, family Enterobacteriaceae. Since 1998, SRE have been divided in two genera: Pectobacterium and Dickeya (Hauben et al., 1998).

The taxonomy of SRE has been changing over the past decades. When the genus Erwinia was classified in 1917, for the first time, it comprised all members of the Enterobacteriaceae that were pathogenic to plants, including both pectinolytic (e.g., Erwinia carotovora and Erwinia chrysanthemi) and non-pectinolytic (Erwinia amylovora) species (Winslow et al., 1917). The name was chosen after one of the first phytopathologists, Erwin Smith. In 1953, Burkholder and coworkers assigned E. chrysanthemi to the genus Erwinia as a pathogen of chrysanthemum. Later studies proved that $E$. chrysanthemi cause disease on a wide variety of plant hosts (Samson et al., 2005; Ma et al., 2007). In 1984, Lelliott and Dickey, on the basis of host specificity, subdivided the species $E$. chrysanthemi into six pathovars (pv.), namely, chrysanthemi, dianthicola, dieffenbachia, paradisiaca, parthenii, and zeae. In 1987, Samson and coworkers developed a biovar system based on their biochemical characteristics (Samson et al., 1987).

Already in 1945, Waldee proposed to move the pectinolytic Erwinia into a new genus Pectobacterium based on their ability to produce pectinolytic enzymes. However, this was not done until 1998 when the 16S rDNA analysis provided more data for this proposal (Hauben et al., 1998). While the potato pathogens $P$. c. subsp. ca- 
rotovorum (syn. $E$ c. subsp. carotovora) and $P$. atrosepticum (syn. E. c. subsp. atroseptica) remain within this genus, a further analysis of $P$. chrysanthemi using $16 \mathrm{~S}$ rDNA, DNA-DNA hybridization and biochemical characterization showed that it formed a distinct clade from Pectobacterium spp., so a new genus, Dickeya, was proposed (named after the microbiologist Robert S. Dickey) (Samson et al., 2005). Samson and coworkers (2005) proposed six species within the genus Dickeya, namely, $D$. chrysanthemi, $D$. dadantii, $D$. dianthicola, $D$. dieffenbachia, D. paradisiaca, and D. zeae. Then, Brady and coworkers (2012) reclassified $D$. dieffenbachiae into $D$. dadantii subsp. dieffenbachiae. In 2014, two new species of Dickeya were proposed: $D$. aquatica and $D$. solani (Parkinson et al., 2014; Van der Wolf et al., 2014b). All currently accepted species and subspecies of Dickeya and Pectobacterium are presented in Table 1.

The SRE are found worldwide and have been isolated from plants of more than half of angiosperm families as well as from soil, rivers, ground waters, insects, molluscs, and nematodes (Perombelon and Kelman, 1980; Perombelon, 2002; Ma et al., 2007; Laurila et al., 2008; Nykyri et al., 2014; Parkinson et al., 2014). They are Gram-stainnegative, rod-shaped, facultative anaerobes that produce a wide range of PCWDE and cause diseases such as blackleg and soft rot. They possess a wide range of hosts including 16 dicotyledonous families of plants in 11 orders and 10 monocotyledonous families in 5 orders (Samson et al., 2005; Ma et al., 2007). Soft rot losses may occur on plants growing in the field, garden, greenhouse, or after harvest during transit, storage, or marketing.

SRE have a climatic distribution that reflects their host diversity and increasing temperatures. Pectobacterium atrosepticumis mainly restricted to temperate climates and almost exclusively to potato. Pectobacterium carotovorum subsp. carotovorum infects a wide variety of plants, and is found in both temperate and tropical zones, causing soft rot to potatoes and many fruits and vegetables (Elphinstone, 1987; Toth, 2003). Dickeya spp. (formerly Erwinia chrysanthemi) affects a wide range of tropi$\mathrm{cal}$ and subtropical plants, including potatoes, many ornamental plants, maize, rice, and pineapple. $D$. dianthicola has not only causes disease of many ornamental plants worldwide, but also has played an important role in potato losses in Europe since the 1970s (Toth et al., 2011). Exemplary hosts of different species of SRE are presented in Table 1.

\section{Soft rot and Blackleg symptoms - what are we dealing with?}

SRE cause blackleg and soft rot diseases. They are often present in latent infections of many crops (Perombelon and Kelman, 1980). The symptoms of soft rot are similar in most plants. The disease symptoms appear first on leaves, stems, and/or underground parts as small, water-soaked, translucent lesions, which gradually enlarge in both diameter and depth. The host tissue softens and becomes squashy or watery. Slimy masses of bacteria and cellular debris frequently seep out from cracks in the tissues. In optimal conditions, within 20 to 72 hours, entire fleshy fruits, roots, tubers, stems and rhizomes, bulbs, corms, buds, leaf stalks, and leaves may rot and collapse, sometimes leaving only the outer skin intact. The decaying tissue may be opaque, white, creamcolored, gray, brown, or black and is always wet. Sometimes, characteristic putrid odor occurs caused by secondary invading bacteria that are growing in the decomposing tissues (Perombelon, 2002).

As the infected seed potato tubers rot in wet soil, new plants do not grow later. Shoots arising from infected tubers become watery, and then they wilt and finally collapse. This potato disease is commonly called blackleg. Blackleg is a soft rot that spreads from infected seed tubers into the stems of new potato plants, and hence, it is a seed-borne disease. If the soil moisture level is lowered, the base of the shoots may become soft, brown to inky black and shriveled. The leaves on such shoots are dwarfed, stiff, curled upward, and are yellowish, red, or bronzed. Affected shoots are also stunted, more upright, and pale in color. Such plants often die prematurely or their yield is reduced (RPD No. 943 July 1990). In Figure 2, symptoms of soft rot and blackleg on potato are presented.

\section{Disease cycle}

For the development of the disease, a compatible interaction between the bacterial strain and the host plant must be established. In addition, the environmental conditions have to be optimal for multiplication and spread of bacteria. Only under favorable conditions (for Dickeya spp., high humidity and favorable temperature), the disease can develop.

Bacteria from genus Dickeya can live as epiphytes or as saprotrophs in soil on the plant debris until they encounter a susceptible host. They are strong compe- 
Table 1. Characteristics of the Dickeya spp. and Pectobacterium spp. and their host range

\begin{tabular}{|c|c|c|}
\hline Species name & Host range & References \\
\hline Dickeya aquatica & $\begin{array}{l}\text { Isolated from water, host plant } \\
\text { not determined }\end{array}$ & Parkinson et al. (2014) \\
\hline $\begin{array}{l}\text { Dickeya chrysanthemi } \\
\text { bv. chrysanthemi }\end{array}$ & $\begin{array}{l}\text { Chrysanthemum spp., } \\
\text { Cynara scolymus, } \\
\text { Cichorium intybus, } \\
\text { Helianthus annuus }\end{array}$ & Samson et al. (2005) \\
\hline $\begin{array}{l}\text { Dickeya chrysanthemi } \\
\text { bv. parthenii }\end{array}$ & $\begin{array}{l}\text { Lycopersicon esculentum, } \\
\text { Parthenium argentatum } \\
\text { Philodendron spp. }\end{array}$ & Samson et al. (2005) \\
\hline Dickeya dianthicola & $\begin{array}{l}\text { Dianthus spp., } \\
\text { Cichorium intybus, } \\
\text { Cynara scolymus, } \\
\text { Dahlia variabilis, } \\
\text { Kalanchoe blossfeldiana, } \\
\text { Lycopersicon esculentum } \\
\text { Solanum tuberosum. }\end{array}$ & Samson et al. (2005) \\
\hline $\begin{array}{l}\text { Dickeya dadantii } \\
\text { subsp. dadantii }\end{array}$ & $\begin{array}{l}\text { Pelargonium capitatum, } \\
\text { Ananas comosus, } \\
\text { Dianthus spp., } \\
\text { Euphorbia pulcherrima, } \\
\text { Ipomoea batatas, } \\
\text { Musa spp., } \\
\text { Philodendron spp., } \\
\text { Saintpaulia ionantha, } \\
\text { Zea mays }\end{array}$ & Samson et al. (2005) \\
\hline $\begin{array}{l}\text { Dickeya dadantii } \\
\text { subsp. dieffenbachiae }\end{array}$ & $\begin{array}{l}\text { Dieffenbachia spp., } \\
\text { Lycopersicon esculentum, } \\
\text { Musa spp. }\end{array}$ & Brady et al. (2012) \\
\hline Dickeya paradisiaca & $\begin{array}{l}\text { Musa spp., } \\
\text { Zea mays }\end{array}$ & Samson et al. (2005) \\
\hline Dickeya solani & Solanum tuberosum & Van der Wolf et al. (2014b) \\
\hline Dickeya zeae & $\begin{array}{l}\text { Zea mays, } \\
\text { Ananas comosus, } \\
\text { Brachiaria ruziziensis, } \\
\text { Chrysanthemum morifolium, } \\
\text { Musa spp., } \\
\text { Nicotiana tabacum, } \\
\text { Oryza sativa, } \\
\text { Solanum tuberosum, }\end{array}$ & Samson et al. (2005) \\
\hline Pectobacterium atrosepticum & $\begin{array}{l}\text { Solanum tuberosum, } \\
\text { Solanum lycopersicum, } \\
\text { Cichorium intybus }\end{array}$ & Gardan et al. (2003) \\
\hline Pectobacterium betavascularum & Beta vulgaris & Gardan et al. (2003) \\
\hline $\begin{array}{l}\text { Pectobacterium carotovorum } \\
\text { subsp. carotovorum }\end{array}$ & $\begin{array}{l}\text { Solanum tuberosum, } \\
\text { Beta vulgaris }\end{array}$ & Hauben et al. (1998) \\
\hline $\begin{array}{l}\text { Pectobacterium carotovorum } \\
\text { subsp. brasiliense }\end{array}$ & Solanum tuberosum & Hauben et al. (1998) \\
\hline $\begin{array}{l}\text { Pectobacterium carotovorum } \\
\text { subsp. odoriferum }\end{array}$ & $\begin{array}{l}\text { Solanum tuberosum, } \\
\text { Cichorium intybus }\end{array}$ & Hauben et al. (1998) \\
\hline Pectobacterium wasabiae & $\begin{array}{l}\text { Armoracia rusticana, } \\
\text { Solanum tuberosum }\end{array}$ & Gardan et al. (2003) \\
\hline
\end{tabular}




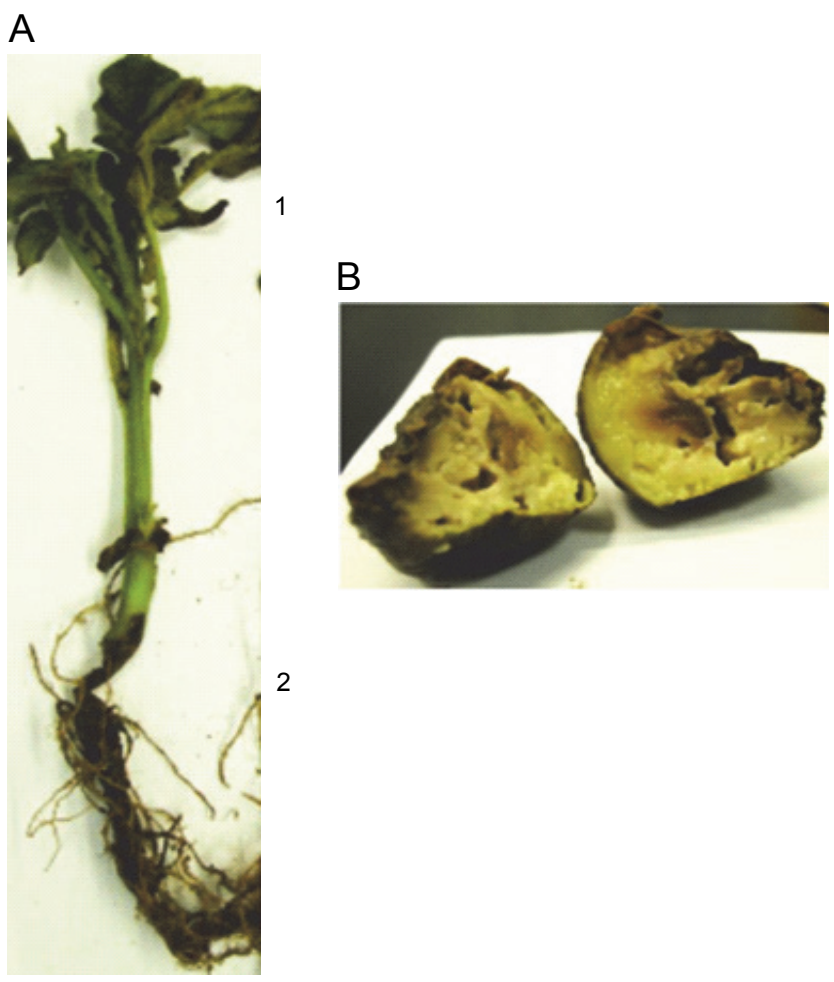

Fig. 2. Symptoms of soft rot and blackleg on potato caused by $D$. solani: A) potato plant: 1 - leaf wilting, 2 - blackleg; B) potato tuber with soft rot, cross section

titive bacteria that eliminate other microbes by contactdependent growth inhibition mechanisms involving type 5 and type 6 secretion systems (T5SS, T6SS) (Charkowski et al., 2012; Pedron et al., 2014). SRE may also infect insects and these may then become dissemination vectors (Grenier et al., 2006). Nykyri and coworkers (2014) also showed that nematodes can act as vectors spreading Dickeya spp.

There are three main steps in the plant infection by bacteria from genera Dickeya and Pectobacterium: 1) adhesion to the plant surface and penetration into the plant tissues either through wounded sites or through natural openings such as stomata, 2) invasion of the apoplasts, and 3) plant cell wall degradation. SRE can reside in the vegetal intercellular spaces, causing a latent infection without any symptoms (Reverchon et al., 2013). If the bacteria encounter advantageous conditions such as favorable temperature, high humidity levels, and poor oxygen availability, the shift of disease symptoms occur (Pérombelon and Kelman, 1980; Pérombelon, 2002). Each of these disease stages requires the detection of information from the environment, and specific inter- action between the host plant and the pathogen population. Reverchon and Nasser (2013) presented a list of genes involved in disease development that have been studied mostly in the $D$. dadantii 3937 strain. This strain has been isolated from Saintpaulia ionantha (Kotoujanski et al., 1982), and most of the genetic studies and virulence factors analyzes have been performed with the use of this strain; therefore, it has been accepted by a scientific community as a model for the molecular study of Dickeya spp.

In spring, the Dickeya species are commonly found on or in the seed tubers, which represent the primary inoculum. In late spring and in summer, bacteria from the infected seed spread to young stems and roots. They multiply in intercellular spaces, degrade the plant cell walls, and liquefy the mother tuber. Progeny tubers may become contaminated with Dickeya spp. as they develop in late summer and early fall. Emerging bacteria may migrate through the soil and infect the neighboring plants. Soft rot occurs when the bacteria gain access to the tuber through wounds and other entry points. Wounds caused during harvest and handling provide multiple points of entry into the tuber, so the infection may spread within the storage containers during storage. Discarded rotten tubers may allow the dispersal of Dickeya spp. in environment (in soil and water). Bacteria from different species of Dickeya and Pectobacterium are able to grow and produce virulence factors in different temperatures. In winter, Dickeya spp. can survive on plant residues in the soil. During the whole disease cycle, insects may be involved in disease spread either because they cause wounds on plant organs on which they feed or deposit their eggs and these allow bacteria to enter the plant, or because they transfer bacteria to other plants, where they might cause disease (Reverchon and Nasser, 2013).

\section{Armory - virulence factors of Dickeya spp.}

Bacteria from genus Dickeya use a combination of different compounds, such as pectin metabolites, acyl homoserine lactones, organic acids that regulate the expression of genes encoding pectate lyases, plant hormones (auxin) and other virulence factors at both transcriptional and post-transcriptional stages. It is thus possible to interfere with soft rot pathogenicity by disrupting these signaling cascades (Charkowski, 2009, 2012). The 
main weapon in the SRE arsenal is the coordinated production of high levels of multiple exoenzymes, including pectinases, cellulases, and proteases, which break down plant cell walls and release nutrients for bacterial growth (Barras et al., 1994; Py et al., 1998; Thomson et al., 1999; Pérombelon, 2002; Hugouvieux-Cotte-Pattat et al., 1996, 2014).

\section{Plant cell wall degrading enzymes (PCWDE)}

\section{Pectinases}

The activity and regulation of pectinases produced by $D$. dadantii 3937 were described by Hugovieux-CottePattat and coworkers in 1996 and reviewed in 2014. The term "pectinases" describes different enzymes cleaving the glycosidic linkages or the methyl-ester bonds of the pectic polymers. Many of these pectinases, such as pectate lyase (Pel), pectin lyase ( $\mathrm{Pnl})$, pectin methyl esterase (Pme), and polygalacturonase (Peh) exist in multiple forms (isoenzymes) encoded by independent genes that, in some cases at least, are clustered and appear to be derived from successive rounds of gene duplication (Barras et al., 1987; McMillan et al., 1994). The D. dadantii3937 strain produces two pectin methyl esterases, at least nine pectate lyases, a polygalacturonase, and a pectin lyase.

Historically, pectate lyases isolated from various organisms were often named as PelA, PelB, PelC, or Pel-1, Pel-2, Pel-3, and so on, depending on either their order of discovery or their characteristics (i.e., their isoelectric point in the case of the first enzymes described in $D . d a-$ dantii3937, (Bertheau et al., 1984)). With such a nomenclature, orthologous pectate lyases often have different names in various strains or Dickeya species. Pectate lyases (Pels) are the main pectinases in pathogenesis and, as with other exoenzymes, their number varies between species, subspecies, and strains. Pectate lyases generally indicate optimal activity at basic $\mathrm{pH}$ (from 7.3 to 9.5$)$ and in the presence of a divalent cation $\left(\mathrm{Ca}^{2+}\right.$ in most cases). They preferentially cleave polygalacturonate $(\mathrm{PG})$ or partially methylated PG. However, the enzymatic properties can differ significantly among different pectate lyases. For instance, the optimal PG methylation level varies from 0 to $50 \%$ among the $D$. dadantii 3937 pectate lyases (Table 2). There are five major Pels that are grouped into two families (Pel A, D, E, and Pel B, C) and at least four secondary Pels (Pel I, L, Z, and $\mathrm{X}$ ) in $D$. dadantii 3937 . The secondary Pels have a lower enzymatic activity than the major ones but appear to play an important role in either the early phase of infection or host specificity (Łojkowska et al., 1995; Jafra et al., 1999; Hugouvieux-Cotte-Pattat et al., 2014). Additional isoenzymes of $\mathrm{Pel}, \mathrm{Pnl}, \mathrm{Pme}$, and Peh are also induced in minimal medium in the presence of both pectate and pectin (McMillan et al., 1994). Pectinases are secreted through the commonly named Out secretion system (Type II Secretion System, T2SS).

All major and secondary pectate lyases present in $D$. dadantii are also present in the genome of $D$. solani and their sequences are homologous to those of $D$. $d a$ dantii 3937; they are also secreted by T2SS (MG, unpublished data).

\section{Cellulases}

The complete degradation of native cellulose to glucose requires three enzymes, namely, endo $\beta$-I, 4 -glucanase, cellobiohydrolase, and $\beta$-glucosidase. Cellulases, which mainly exhibit endoglucanase (EG) activity, break down cellulose in the primary and secondary cell walls of the host plant. D. dadantii 3937 produces two EGs: EGZ, which comprises the major activity and is secreted and EGY, which is less abundant and is periplasmic (Barras et al., 1994). The genes encoding these enzymes are $c e l Z$ and $c e l Y$, respectively. They seem to be inessential for pathogenicity, but they do appear to act in synergy with other exoenzymes of various classes (i.e., pectinases) to attack the plant cell wall (Boccara et al., 1994). EGZ is secreted by so-called Out general secretion pathway (T2SS). EGZ contains two functionally independent domains: a catalytic domain (CD) and a cellulose-binding domain (CBD) joined by a Ser/Thr-rich linker region (LR) (Py et al., 1991). Both genes coding cellulases are present in the genome of $D$. solani and their sequences are identical to those of $D$. dadantii 3937 (MG, unpublished data).

\section{Proteases}

Many plant-pathogenic bacteria produce proteases. Dickeya strains produce metalloproteases A, B, C, and G (Delepelaire and Wandersman, 1990; Ghigo and Wandersman, 1992). The proteases are secreted into the external medium via Type I Secretion system, of which two are inactive precursors (zymogens B and C) where they are activated by divalent cations. Metalloproteases may 
Table 2. Characteristics of $D$. dadantii 3937 pectate lyases

(Modified after Hugouvieux-Cotte-Pattat et al. 2014)

\begin{tabular}{|c|c|c|c|c|c|}
\hline Name & $\begin{array}{l}\text { PL family } \\
\text { (subfamily) }\end{array}$ & $\begin{array}{c}\text { Substrate } \\
\text { (optimal methylation) }\end{array}$ & $\begin{array}{l}\text { Optimal } \\
\mathrm{pH}\end{array}$ & Cation(s) & $\begin{array}{c}\text { Cell location } \\
\text { (secretion system) }\end{array}$ \\
\hline PelZ & $1(2)$ & PG (0 to $20 \%)$ & $8.5-9.0$ & $\mathrm{Mn}(\mathrm{Ca})$ & external (Out) \\
\hline PelB & $1(3)$ & PG (0 to $40 \%)$ & $9.0-9.5$ & $\mathrm{Ca}$ & external (Out) \\
\hline PelC & $1(3)$ & PG (0 to $20 \%)$ & $9.0-9.5$ & $\mathrm{Ca}$ & external (Out) \\
\hline PelA & $1(6)$ & $\mathrm{PG}(0 \%)$ & 8.5 & $\mathrm{Ca}$ & external (Out) \\
\hline PelD & $1(6)$ & PG (0\%) & 8.5 & $\mathrm{Ca}$ & external (Out) \\
\hline PelE & $1(6)$ & PG $(0 \%)$ & 8.0 & $\mathrm{Ca}$ & external (Out) \\
\hline PnlH & $1(8)$ & & & & outer membrane (Stt) \\
\hline PelW & $2(2)$ & $\mathrm{G} 3, \mathrm{G} 4, \mathrm{PG}(0$ to $60 \%)$ & 8.5 & Co, $\mathrm{Mn}, \mathrm{Ni}$ & cytoplasm \\
\hline PelI & $3(5)$ & PG (0 to $50 \%)$ & 9.2 & $\mathrm{Ca}$ & external (Out) \\
\hline PelL & $9(1)$ & PG (0 to $30 \%)$ & $8.0-9.0$ & $\mathrm{Ca}$ & external (Out) \\
\hline PelN & $9(1)$ & PG (0 to $90 \%)$ & 7.4 & $\mathrm{Fe}$ & external (Out) \\
\hline PelX & $9(1)$ & $\mathrm{G} 4$ to $\mathrm{G} 7, \mathrm{PG}(0$ to $20 \%)$ & $8.0-8.5$ & $\mathrm{Ca}(\mathrm{Mn}, \mathrm{Co}, \mathrm{Ni})$ & periplasm \\
\hline
\end{tabular}

PG - polygalacturonate; G3, G4, G7 - saturated galacturonates; Out - type 2 secretion system

play a role in virulence by degrading plant cell wall proteins. They may either provide amino acids for biosynthesis of microbial proteins or lead to degradation of host proteins associated with resistance (Heilbronn and Lyon, 1990; Kyöstiö et al.,1991) or, according to the literature, have a minor role like cellulases, in pathogenesis (Marits et al., 2002).

\section{Motility}

Phytopathogenic bacteria can be motile by means of flagella, and genes coding for flagellar proteins contribute to virulence and to host-pathogen interactions, that is, for Dickeya - potato interaction (Van Vaerenbergh et al., 2012). Two different types of motility require the presence of bacterial flagella - swimming, which takes place in liquid media and swarming motility, on solid surfaces or in media of high viscosity. The ability to swarm can be dependent upon the growth media and temperature. The analysis of the virulence of the mutants in different host plants indicated that motility and chemotaxis play an important role in the pathogenicity of $D$. dadantii 3937 (Antunez-Lamas et al., 2009a,b). The results presented by Antunez-Lamas and coworkers (2009a) indicated that mutations affecting motility/chemotaxis (in genes mot $A$ and $c h e Y$ ) had an influence on the $D$. dadantii 3937 virulence toward several hosts, such as chicory,
Saintpaulia, and potato. The mutants' motA and $c h e Y$ showed a significant reduction of their virulence in those hosts. Motility/chemotaxis also plays a role in colonization of potato tubers (Antunez-Lamas et al., 2009b).

\section{Iron uptake}

Another process that is crucial for pathogenesis is iron uptake, which initially was linked to pathogenicity in $D$. dadantii 3937 through the analysis of bacteriocinresistant mutants (Franza et al., 2005). Iron is a necessary cofactor for enzymes involved in important cellular functions. Bacteria from genus Dickeya regulate gene expression in response to iron. For example, low iron availability is a signal that triggers transcription of the genes encoding major pectate lyases PelD and PelE, as well as the genes that are involved in iron transport. This regulation is mediated by the transcriptional repressor Fur, Ferric Uptake Regulator (Franza et al., 2005). D. dadantii 3937 produces two siderophores: chrysobactin and achromobactin, in order to acquire iron from the iron-poor environment of the plant apoplast. Several studies demonstrated that the presence of chrysobactin and achromobactin highly contributes to the successful infection of the plant (Franza et al., 2005; Dellagi et al., 2005). Mutants defective in chrysobactin-mediated iron transport remain localized within Saintpaulia leaves, sug- 
gesting a role in bacterial spread throughout the plant (Franza et al., 2005). The virulence of achromobactindeficient mutants are also affected, but they are more aggressive than the chrysobactin non-producers; and double mutants, deficient in both achromobactin and chrysobactin production, are impaired in symptom initiation.

An analysis of Dickeya spp. and Pectobacterium spp. genomes revealed multiple TonB-dependent outer membrane receptors and TonB homologs (TonB-dependent transporters are bacterial outer membrane proteins that bind and transport ferric chelates), suggesting that the capacity of using diverse exogenous siderophores is common among SRE and may confer fitness in complex environments (Schauer et al., 2008). A study of $P$. atrosepticum SCRI1043 and D. dadantii 3937 revealed that besides the production and utilization of siderophores, they have the capacity to use other iron sources through siderophore-independent systems, such as Feo, Efe, UOB, or Hmu systems (reviewed by Franza and Expert, 2013). Both species are also able to uptake the haemiron, while $P$. atrosepticum SCRI1043 can only transport the ferric citrate complex and only $D$. dadantii 3937 can acquire ferrous iron system (Franza and Expert, 2013).

\section{Quorum sensing communications systems}

Virulence genes are expressed in a concerted manner and they culminate when the bacterial quorum is reached. Numerous Gram-stain-negative species use acylhomoserine lactone (AHL)-based quorum sensing (QS) system Exp to regulate the expression of genes involved in interactions with host cells. In Pectobacterium spp., which produces 3-oxo-C6-HSL and 3-oxo-C8-HSL, the AHL QS system is at the top of a regulatory cascade controlling over a quarter of the Pectobacterium spp. genes, including key virulence factors, such as pectinase, cellulase, and protease activities, and production of $\mathrm{HrpN}$, a protein secreted via type III secretion system (T3SS) (Liu et al., 2008; Charkowski et al., 2012). Expression of the virulence genes encoding PCWDE is activated only when a sufficient amount of the AHL signal molecule has accumulated (Andersson et al., 2000). Expression of those genes is also induced by pectin metabolites. Pectin is both one of the main components of the plant cell wall and a carbon source that SRE are able to exploit. In contrast, in the closely related $D$. dadantii 3937 , AHL ap- pear to play a minor role in virulence gene regulation. Specific interactions have been observed in vitro between the AHL-related QS regulator ExpR and pelgene promoters, but no specific phenotype was associated to the expIor expRmutations (Nasser et al., 2013). In addition AHL-based QS system of $D$. dadantii 3937 does not play a pivotal role in the cell density-dependent control of virulence gene expression in vitro or in planta (Reverchon et al., 2002; Mhedbi-Hajri et al., 2011).

Besides AHL-based QS, a new communication system has been discovered in $D$. dadantii 3937 called Virulence Factor Modulating (Vfm) cluster (Nasser et al., 2013). The Vfm cluster does not seem to be widespread among bacterial species but is conserved in Dickeya species; the Vfm cluster is absent from the related pectinolytic enterobacteria of the Pectobacterium genus (Nasser et al., 2013). Studies on the mutants with decreased production of all PCWDE that could be complemented by cell-free culture supernatant have revealed that Vfm cluster controls the transcription of the PCWDE genes (Nasser et al., 2013).

Both QS systems, Exp and Vfm gene clusters, are present and they play an important role in the regulation of the biosynthesis of genes coding PCWDE in D. solani (Potrykus et al., 2014a; M. Potrykus, unpublished results). The work of Potrykus and coworkers (2014a) reveals the role of QS mediated by ExpI and ExpR in D. solani virulence on potato.

\section{Not only the bullets, also the guns - secretion systems and their role in Dickeya spp. cells}

Protein export is the key in the virulence of Dickeya spp. (Glasner et al., 2011; Garlant et al., 2013; Pedron et al., 2014). The rapid induction of expression of genes coding for exoenzymes and other pathogenicity factors within the bacterial cell is of little consequence, unless they can be efficiently targeted to the extracellular environment. To accomplish this, bacteria from Dickeya genus have all six secretion systems that are common for Gram-stain-negative bacteria, all of which exhibit very different mechanisms that appear to be conserved within SRE. These systems are involved in attacking host plants and competing bacteria (Charkowski et al., 2012).

Type I Secretion System (T1SS) secretes proteases from the cytoplasm to the extracellular space in a single step, but while this system has been studied in detail in 
Dickeya spp., it appears to have a relatively minor role in pathogenicity (Dahler et al., 1990; Delepelaire and Wandersman, 1990; Létoffé et al., 1990). In Pectobacterium spp., the T1SS is upregulated by plant extracts and AHL-based QS, and controlled by GacAS regulator (Marits et al., 2002). In Dickeya spp., this system is controlled by PecS global negative regulator (Hommais et al., 2008; Mhedbi-Hajri et al., 2011) and GacAS (Reverchon et al., 2013). T1SS-associated ABC transporters with a noncatalytic $\mathrm{C} 39$ peptidase-like domain tend to secrete large, 50 to $1000 \mathrm{kDa}$, repeats-in-toxin (RTX) proteins with uncleaved $\mathrm{C}$-terminal secretion signals (Linhartova et al., 2010). In D. dadantii 3937, RTX proteases (PrtG, PrtB, PrtC, and PrtA) are secreted by a T1SS (Letoffe et al., 1990; Delapelaire and Wandersman, 1990; Ghigo and Wandersman, 1992; Charkowski et al., 2012). Two of the proteases (PrtB, PrtC) are secreted as zymogens that are activated after secretion by divalent cations (Delapelaire and Wandersman, 1989). These characteristics are similar to other RTX metalloproteases, which belong to a subgroup of proteases with an extended zincbinding motif (Linhartova et al., 2010). D. dadantii 3937 also exports a protease inhibitor to the periplasmic space in a Sec-dependent manner that is superficially analogous to the contact-dependent growth inhibition mechanism, but the inhibitor is nonspecific and can inhibit many proteases (Letoffe et al., 1989). Additionally, RTX protease mutants of $P$. carotovorum are modestly affected in virulence, suggesting a role in plant pathogenesis rather than toxicity against other bacteria (Marits et al., 2002).

Type II secretion system (T2SS), also called Out system, is essential for pathogenicity and it secretes pathogenicity determinants, such as pectinases and cellulases in a two-step mechanism. The first step is a Sec-dependent protein export system that exports proteins to the periplasm. The second step, controlled by a 15 -gene Out cluster, includes the formation of a structure that spans the periplasmic compartment and outer membrane and channels proteins, recognized by a signal sequence, to the outside of the cell. Type II-secreted proteins have been identified during individual enzyme studies and enzyme or global secretome analyzes of $D$. dadantii or $P$. atrosepticum (Salmond et al., 1994; Charkowski et al., 2012). However, despite a high level of interspecies amino acid identity within the SRE, Out genes from P. c. subsp. carotovorum (strain SCRI193) do not com- plement mutations in equivalent genes in $D$. dadantii 3937 and vice versa, suggesting a degree of species-specificity (Py et al., 1991). Regulation of Type II system is, at least in part, under the control of KdgR global negative regulator and may also operate under a QS mechanism (Charkowski et al., 2012).

Type III secretion system (T3SS) has been more closely examined in hemibiotrophic phytopathogenic bacteria, such as Pseudomonas syringae, than in SRE, but is required for pathogenesis in both bacterial groups. Unlike $P$. syringae, which can have up to 30 potential type III - secreted effector proteins in individual strains, Pectobacterium spp. appear to have relatively few (Holeva et al., 2004; Kim et al., 2011), including a small number of harpins or helper proteins and the single known effector, DspA/E. Holeva and coworkers (2004) demonstrated that the T3SS helper HrpN and effector DspE/A are required for pathogenicity in $P$. atrosepticum.

In comparison to other secretion systems, type IV secretion system (T4SS) is unique in its ability to transport nucleic acids in addition to proteins into plant and animal cells, as well as into yeast and other bacteria (Christie et al., 2005). Genes that encode a similar system were discovered in the complete genome sequence of $P$. atrosepticum SCRI1043, and further investigation revealed that a mutation in the T4SS reduced its virulence on potato (Bell et al., 2004).

Type V secretion systems (T5SSs) have relatively simple structures and they are reviewed by Leo and coworkers (2012). T5SSs are subtyped into T5aSS-T5eSS on the basis of differences in the structure and mechanism of secretion. The functions of the T5SS secreted proteins are variable, but include serine proteases, lipases, cytotoxins, invasins, and adhesins that collectively generalize to influencing bacterial fitness, aggregation, biofilm formation, and virulence (Grijpstra et al., 2013). The T5SSs have also been implicated in a phenomenon referred to as contact-dependent growth inhibition, where, upon contact, toxic proteins are targeted to another bacterium (Ruhe et al., 2013). In D. dadantii, a $>3,800$ amino acid-long protein with homology to T5bSS adhesins was demonstrated to be necessary for bacterial adhesion to the surface of leaves, aggregation of bacteria, and incitation of host cell death (Rojas et al., 2002). On the basis of C-terminal extensions with homology to proteins toxic to bacteria, these putative T5SSs 
likely function to suppress the growth of competing bacteria rather than suppressing their virulence toward plants (Ruhe et al., 2013)

Type VI secretion system (T6SS) is the most recently described of the Gram-stain-negative bacterial secretion systems and is widely distributed among diverse species. The T6SS has been shown to play an important role in pathogenicity toward eukaryotic host cells in a variety of important human pathogens, including Pseudomonas aeruginosa, Burkholderia mallei, Vibrio cholerae, and Aeromonas hydrophila (English et al., 2014). It is now clear that the T6SS can also be used to target other bacteria and is thus likely to play an important role in polymicrobial infections. Various Type VI-secreted antibacterial toxins have recently been identified. The biggest groups are peptidoglycan hydrolases including several families of peptidoglycan amidase and glycoside hydrolase enzymes, which attack the cell wall of target bacteria (Russell et al., 2012; Whitney et al., 2013). Additionally, a superfamily of phospholipase effectors, attacking the target cell membrane, were described recently and a small number of other, unrelated effector toxins have been experimentally identified, such as antimicrobial toxins and phopsholipases, but they are yet to be fully characterized (Russell et al., 2013). In P. atrosepticum, the T6SS-encoding genes are induced in response to potato extracts (Mattinen et al., 2008). P. wasabiae SCC3193 has two putative T6SSs and a large inventory of putative tail and spike homologs (Nykyri et al., 2012).

A mutant with deletions of unlinked genomic regions spanning 16 and 23 genes that included the two putative T6SS-encoding loci was modestly affected in its virulence on potato tuber slices (Nykyri et al., 2012). Pedron and coworkers (2014) revealed that $D$. solani genome encodes a distinctive arsenal of T5SS- and T6SS-related toxin-antitoxin systems.

\section{Regulation - when and where to use armory?}

Virulence determinants in the Dickeya are controlled by complex regulatory networks, which act either positively or negatively on one (targeted regulation) or several (global regulation) determinants. They are stimulated by factors such as oxygen and nitrogen availability, temperature, $\mathrm{pH}$, osmolarity, iron deprivation, growth phase, catabolite repression, plant degradation intermediates, plant extracts, DNA-damaging agents, and other factors yet to be identified. Newly identified regulatory proteins, thanks to a better understanding of the existing ones, (Nasser et al., 2005; Nguyen et al., 2002) continue to be added to the list of known regulators that have been reviewed extensively by HugouvieuxCotte-Pattat et al. (1996) and Thomson et al. (1999).

Three regulatory loci, $k d g R$, pecS, and pecT, have been identified as the regulators that negatively control the expression of genes encoding pectinases in $D$. $d a-$ dantii 3937 (Nasser et al., 2005; Praillet et al., 1997; Reverchon and Nasser, 2013; Surgey et al., 1996). Among these regulators, the KdgR protein is the main effector and it acts as a transcriptional repressor for all the genes coding for proteins involved in the pectin degradation pathway. In D. dadantii 3937, in the absence of pectic inducers, the KdgR protein binds to a specific 17-bp sequence (the KdgR box), which is conserved in the promoter region of the whole spectrum of genes encoding pectinases (Nasser et al., 2005). PecS negatively controls the production of pectinases and cellulases, as well as the production of the blue pigment indigoidine (antioxidant molecule), motility, and the harpin HrpN (Reverchon et al., 1994, 2002; Rouanet et al., 2004; Nasser et al., 2005). PecT represses the production of pectinases, EPS, motility, and the harpin HrpN (Surgey et al., 1996; Castillo and Reverchon, 1997; Condemine et al., 1999; Nasser et al., 2005).

Pectinase production is also positively regulated. The cAMP receptor protein (CRP) activates the transcription of the pectinolysis genes (Nasser et al., 2005). The histone-like nucleoid-structuring (H-NS) protein (a protein that influences nucleus structure and gene expression in response to numerous growth parameters) plays an important role within the pel gene regulatory network (Nasser et al., 2005). The studies have shown that H-NS is involved in the $D$. dadantii 3937 pel virulence pathway by exerting a negative effect on the expression of at least three regulatory loci, namely, expI, $\exp R$ and $p e c T$. For example, inactivation of H-NS results in the overproduction of PecT, which will in turn reduce the transcription of pel genes (Reverchon and Nasser, 2013).

The work of Potrykus and coworkers (2014a) revealed the role of KdgR, PecS, PecT, ExpI, and ExpR regulators in $D$. solani strains. Mutants of four $D$. solani strains were constructed by inactivating the genes coding either for one of the global negative regulators of 
D. dadantii3937 virulence ( $k d g R$, pecS, and pecT) or for the synthesis and perception of signaling molecules (expIand $\operatorname{expR}$ ). An analysis of these mutants indicated that PecS, PecT, and KdgR play a similar role in $D . d a-$ dantii and $D$. solani cells, regulating the expression of genes coding pectinases, cellulases, and proteases. The thermoregulator PecT seems to be a major regulator of D. solani virulence (Potrykus et al., 2014a).

\section{Identification and differentiation of the bacteria from genus Dickeya}

The detection, identification, and differentiation of Dickeya spp. have been reviewed in an article recently published by Czajkowski and coworkers (2015). Here, we present only a short description of methods used for those purposes.

\section{Phenotypic methods}

The most used worldwide medium for isolation of Dickeya and Pectobacterium cells is CVP medium (Crystal Violet Pectate) (Helias et al., 2012). Detection of Dickeya spp. on CVP depends on the formation of characteristic deep cavities by the bacterial colonies. When the bacterial population are low, they need to be enriched above the detection level (Pérombelon, 2002). The tested material is incubated under anaerobic conditions in a liquid enrichment medium, PEB, containing sodium polypectate as the sole carbon source (Pérombelon and van der Wolf, 2002). The NGM medium was developed to differentiate Dickeya spp. from Pectobacterium spp. on the basis of the ability to produce the blue pigment, indigoidine (Lee and $\mathrm{Yu}, 2005$ ).

In the past, biochemical tests were commonly used to differentiate strains of Pectobacterium spp. and Dickeya spp. from other bacteria. As the procedures are troublesome and time consuming, they were replaced with more rapid serological and molecular methods (Czajkowski et al., 2015). Palacio-Bielsa and coworkers (2006) developed a modern version of a biochemical test using a microtiter system for differentiation of Dickeya species. Sławiak and coworkers (2009a) modified the method and checked features such as, growth at $39^{\circ} \mathrm{C}$, $41^{\circ} \mathrm{C}$ and $25^{\circ} \mathrm{C}$ on nutrient broth, anaerobic hydrolysis of arginine and polysaccharide inulin utilization in phenol red peptone water (inulin extracts from chicory and dahlia were used at $0.3 \%$ final concentration); eight carbon sources were tested by acidification/alkalization on liquid Ayers, Rupp and Johnson medium with bromothymol blue mixed with different $0.3 \%$ carbohydrates: (-)-D-arabinose, 5-keto-D-gluconate, mannitol, (+)-Dmelibiose, $(+)$-D-raffinose and (-)-D-tartrate, $\beta$-gentiobiose and (+)-L-tartrate.

Other phenotypic methods used for distinguishing SRE are fatty acid methyl ester analysis, volatiles profiling, serological methods, immunofluorescence staining, and immunofluorescence colony staining (Czajkowski et al., 2015).

\section{Genotyping methods}

Molecular detection methods based on the analysis of bacterial genomic DNA have become the most frequently used methods to detect and differentiate tuber soft rot and blackleg pathogens in environmental samples. These are methods that can be applied to the mixture of bacterial strains and allow detection and identification of pathogens present in symptomatic or symptomless plant samples. Several single-PCR and multiplexPCR assays with species-specific primers have been developed for the detection of soft rot and blackleg pathogens; multiplex-PCR assays can simultaneously detect a few kinds of pathogens in the tested sample. In our laboratory, a multiplex-PCR assay has been developed, which detects and distinguishes SRE from P. c. subsp. carotovorum, $P$. wasabiae, $P$. atrosepticum, and Dickeya spp. (Potrykus et al., 2014b). Real-time PCR procedures have also been developed for the detection of bacteria from the genus Dickeya and Pectobacterium(Brierley et al., 2008; Laurila et al., 2010; Kim et al., 2011, Pritchard et al., 2012; Van der Wolf et al., 2014a). Pritchard and coworkers (2012) presented a bioinformatics tool allowing an easy prediction of primer sets for specific detection of species and subspecies of Dickeya based on the raw genome sequence information.

On the other hand, there are more sophisticated methods for differentiating closely related strains, but they require isolation of pure bacterial culture. Restriction fragment length polymorphism of amplified PCR (PCRRFLP) product (usually one of the housekeeping genes) may be applied specifically for the identification and differentiation of closely related isolates within species and subspecies. To differentiate between Pectobacterium and Dickeya species, two groups of genes were mainly used; those coding for virulence factors, such as pelgenes (Darrasse et al., 1994) and the housekeeping genes, 
such as $16 \mathrm{~S}$ rDNA, 23S rDNA, recA, gyrA, gyrB, rpoS, and $d n a X$. Waleron and coworkers (2002ab, 2013) developed a PCR-RFLP assay to differentiate pectinolytic Pectobacterium and Dickeya species on the basis of the sequences of housekeeping genes recA and rpoS.

A multilocus sequence analysis (MLSA) using concatenated sequences of the intergenic spacer (IGS), as well as $d n a X$, recA, dnaN, fusA, gapA, purA, rplB, rpoS, and gyrA have been used in the study of Dickeya species regarding the establishment of $D$. solanigenus (van der Wolf et al., 2014b). This study revealed that the group of $D$. solani is homogenous and distinct from other Dickeya species.

The methods mentioned above have been developed on the basis of single genes, but there are also methods applying a whole-genome approach such as repetitive sequence-based PCR (rep-PCR) or pulsed-field gel electrophoresis (PFGE) and, of course, genomes sequencing which are described below. Repetitive sequence-based PCR (rep-PCR) has been developed to target the repetitive sequences present in bacterial genomes, namely, Repetitive Extragenic Palindromic (REP) sequences, Enterobacterial Repetitive Intergenic Consensus (ERICPCR), and BOX elements (BOX-PCR) (Versalovic et al., 1991 and 1994). The relative resolution of the generated patterns is high and allows phylogenetic classification of SRE from the genus down to the strain level. The repPCR analyzes were used, for example, in studies on the classification of a new clade of Dickeya spp. biovar 3 (Sławiak, 2009b) and D. solani (Degefu et al., 2013; Potrykus et al., 2016). The technique is easy to perform and its resolution is high. The macrorestriction analysis by PFGE described by Ribot et al. (2001) was successfully applied to confirm the identity and homogeneity of D. solani strains isolated in Finland, Israel, and Poland (Degefu et al., 2013; Tsror et al., 2009, 2013; Potrykus et al., 2016). Another method used for genotyping of D. dianthicola and $D$. solani on the basis of a whole genome is a variable number tandem repeat (VNTR) analysis; it allows to differentiate 19 profiles characteristic of $D$. dianthicola and only 3 profiles characteristic of D. solani (Parkinson et al., 2015).

The development of next-generation sequencing (NGS) techniques lets the scientists to delve into more detailed search for the differences among the strains of same or different species (Toth et al., 2003; Pritchard et al., 2012). Complete or draft genome sequences are now available for numerous strains from the genus Dic- keya and Pectobacterium, with many more in draft formats. In the National Center for Biotechnology Information (NCBI) genomes database, already 53 genomes assemblies of Pectobacterium spp. and 41 genome assemblies of Dickeya spp. are available (http://www.ncbi.nlm. nih.gov/). A typical member of this group has a single circular chromosome of around $5 \mathrm{Mb}$ and no large plasmids are present. Comparative genomics can reveal physiological and functional variation among bacteria that provide insight into their ability to exploit distinct ecological niches (Toth et al., 2006). Genome sequences provide a valuable resource for the discovery of molecular markers that can be used for reliable classification of prokaryotic taxa and for understanding evolutionary relationships among them (Lerat et al., 2005; Dutilh et al., 2008; Gupta, 2010; Bhandari et al., 2012; Gao and Gupta, 2012). The complete genome sequence of $D$. dadantii 3937 (Glasner et al., 2011) as well as genome sequences of seven $D$. solani strains at different stages of assembly have been published (Garlant et al., 2013; Pritchard et al., 2013a,b; Khayi et al., 2014; Golanowska et al., 2015).

\section{Control of disease caused Dickeya spp.}

Effective control of blackleg and soft rot diseases of potatoes caused by bacteria from the genus Dickeya has not yet been achieved although many different methods were employed. Disease control is based primarily on avoidance of bacterial contamination during the production of healthy certified seed (Czajkowski et al., 2011). This should be achieved by producing seed potato from bacteria-free minitubers, by the application of seed certification schemes and strict hygienic practices. Knowledge of the pathogen sources and contamination pathways and effective methods for detection of pectinolytic bacteria together with the application of hygienic measures during harvest and post-harvesting storage should allow the production of healthy plant material. The recent appearance of apparently more virulent strains of Dickeya spp. - D. solani - should also give a new impact on the development of new, efficient diagnostics tools for control of seed potato and other crop contamination and breeding of new cultivars with a higher level of resistance to pectinolytic bacteria than currently growing cultivars.

Progress related to enhanced resistance to pectinolytic bacteria in new cultivars is expected, since there 
are new tools now available and breeders may be used for more efficient introduction and maintenance of desired traits in breeding pool. They include DNA markers providing tools for the analysis of QTL controlling genetic resistance and marker-assisted selection, better understanding of the host-pathogen interaction at the molecular level, new techniques for genetic improvement of potato by application of somatic hybridization, and transgenic approach besides sexual crosses conventionally in use (Zimnoch-Guzowska et al., 2005). Another possibility is control of SRE by newly isolated and fully characterized bacteriophages, specific for the broad range Dickeya spp. and Pectobacterium spp. strains (Czajkowski et al., 2015).

\section{Conclusions}

The review presented here sums up the available information about new, economically important plant pathogenic bacteria from the genus Dickeya. D. solani strains isolated in the past 10 years in different countries, including Poland, form a very homogenous group, whose genome contains all genes involved in the pathogenicity of SRE including a full set of plant cell wall degrading enzymes and at least two QS systems. The genome of $D$. solani contains two sets of virulence factors, such as polyketide synthases and non-ribosomal peptide synthetases as well as effective T6 secretion system effectors. There is a need for intense research on the factors involved in the pathogenicity of $D$. solani. This is especially important because of the lack of efficient chemical and biological means to fight these bacteria.

\section{Acknowledgments}

We thank M. Potrykus for the photos of soft rot and blackleg symptoms on potato. This work was supported by grants from the National Science Center NSC 2013/08/M/NZ9/00974 and UMO-2014/14/M/ NZ8/00501 to E. Lojkowska

\section{References}

Antunez-Lamas M., Cabrera-Ordonez E., Lopez-col E., Raposo R., Trelles-Salazar O., et al. (2009a) Role of motility and chemotaxis in the pathogenesis of Dickeya dadantii 3937 (ex Erwinia chrysanthemi 3937). Microbiology 155: 434442.

Antunez-Lamas M., Cabrera E., Lopez-Solanilla E., Solano R., Gonzalez-Melendi P., et al. (2009b) Bacterial chemoattraction towards jasmonate plays a role in the entry of Dickeya dadantii through wounded tissues. Mol. Microbiol. 74: 662-671.
Andersson R.A., Eriksson A.R., Heikinheimo R., Mäe A., Pirhonen M., Kõiv V., Hyytiäinen H., Tuikkala A., Palva E.T. (2000) Quorum sensing in the plant pathogen Erwinia carotovora subsp. carotovora: the role of expR $(E c c)$. Mol. Plant Microbe Inter. 13: 384-393.

Barras F., Thurn K.K., Chatterjee A.K. (1987) Resolution of four pectate lyase structural genes of Erwinia chrysanthemi (EC16) and characterization of the enzymes produced in Escherichia coli. Mol. Gen. Genet. 209: 319-325.

Barras F., Van Gijsegem F., Chatterjee A.K. (1994) Extracellular enzymes and pathogenesis of soft-rot Erwinia. Annu. Rev. Phytopathol. 32: 201-234.

Bell K.S., Sebaihia M., Pritchard L., Holden M.T.G., Hyman L.J., Holeva M.C., Thomson N.R., Bentley S.D., Churcher L.J.C., Mungall K. et al. (2004) Genome sequence of the enterobacterial phytopathogen Erwinia carotovora subsp. atroseptica and characterization of virulence factors. Proc. Natl. Acad. Sci. USA 101: 11105-11110.

Bertheau Y., Madgidi-Hervan E., Kotoujansky A., Nguyen-The C., Andro T., et al. (1984) Detection of depolymerase isoenzymes after electrophoresis or electrofocusing, or in titration curves. Anal. Biochem. 139: 383-389.

Bhandari V., Naushad H.S., Gupta R.S. (2012) Protein based molecular markers provide reliable means to understand prokaryotic phylogeny and support Darwinian mode of evolution. Front Cell Infect. Microbiol. 2: 98.

Boccara M., Aymeric J.L., Camus C. (1994) Role of endoglucanases in Erwinia chrysanthemi 3937 virulence on Saintpaulia ionantha. J. Bacteriol. 176: 1524-1526.

Brady C.L., Cleenwerck I., Denman S., Venter S.N., Rodriguez-Palenzuela P., Coutinho T.A., De Vos P. (2012) Proposal to reclassify Brenneria quercina (Hildebrand and Schroth 1967) Hauben et al. 1999 into a new genus, Lonsdalea gen. nov., as Lonsdalea quercina comb. nov., descriptions of Lonsdalea quercina subsp. quercina comb. nov., Lonsdalea quercina subsp. iberica subsp. nov. and Lonsdalea quercina subsp. britannica subsp. nov., emendation of the description of the genus Brenneria, reclassification of Dickeya dieffenbachiae as Dickeya dadantii subsp. dieffenbachiae comb. nov., and emendation of the description of Dickeya dadantii. Inter. J. System. Evol. Microbiol. 62: 1592-1602.

Brierley J., Lees A., Hilton A., Wale S., Peters J., Elphinstone J., Boonham N. (2008) Improving decision making for the management of potato diseases using real-time diagnostics. Potato Council Final Report, 253.

Castillo A., Reverchon S. (1997) Characterization of the pecT control region from Erwinia chrysanthemi 3937. J. Bacteriol. 179: 4909-4918.

Charkowski A., (2009) Decaying signals: will understanding bacterial-plant communications lead to control of soft rot. Curr. Opin. Biotech. 20: 1-7.

Charkowski A., Blanco C., Condemine. G, Expert D., Franza T., Hayes C., Hugouvieux-Cotte-Pattat N., López Solanilla E., Low D., Moleleki L. et al. (2012) The role of secretion systems and small molecules in soft-rot enterobacteriaceae pathogenicity. Ann. Rev. Phytopathol. 50: 425-449. 
Chen X.F., Zhang H.L., Chen J. (2015) First report of Dickeya solani causing soft rot in imported bulbs of Hyacinthus orientalis in China. Plant Dis. 99: 155.

Christie P.J., Cascales E. (2005) Structural and dynamic properties of bacterial type IV secretion systems (review). Mol. Mem. Biol. 22: 51-61.

Condemine G., Castillo A., Passeri F., Enard C. (1999) The PecT repressor coregulates synthesis of exopolysaccharides and virulence factors in Erwinia chrysanthemi. Mol. Plant Microbe Inter. 12: 45-52.

Czajkowski R., de Boer W.J., Velvis H., van derWolf J.M. (2010) Systemic colonization of potato plants by soil borne, GFP-tagged strain of Dickeya sp. biovar 3. Phytopathology 100: 134-142.

Czajkowski R., Perombelon M.C.M., van Veen J.A., van der Wolf J.M. (2011) Control of blackleg and tuber soft rot of potato caused by Pectobacterium and Dickeya species: a review. Plant Pathol. 60: 999-1013.

Czajkowski R., de Boer W.J., van der Zouwen P.S., Kastelein P., Jafra S., de Haan E.G., van den Bovenkamp G.W., van der Wolf J.M. (2013) Virulence of 'Dickeya solani' and Dickeya dianthicola biovar-1 and -7 strains on potato (Solanum tuberosum). Plant Pathol. 62(3): 597-610.

Czajkowski R. Ozymko Z., de Jager V., Siwińska J., Smolarska A., Ossowicki A., Narajczyk M., Łojkowska E. (2015) Genomic, proteomic and morphological characterization of two novel broad host lytic bacteriophages $\varphi$ PD10.3 and $\varphi$ PD23.1 infecting pectolytic Pectobacterium spp. and Dickeya spp. PLOS One, doi: 10.137.

Czajkowski R., Pérombelon M. C. M., Jafra S., Łojkowska E., Potrykus M., van der Wolf J. M., Śledź, W. (2015). Detection, identification and differentiation of Pectobacterium and Dickeya species causing potato blackleg and tuber soft rot: a review. Ann. App. Biol. 166: 18-38.

Dahler G.S., Barras F., Keen N.T. (1990) Cloning of genes encoding extracellular metalloproteases from Erwinia chrysanthemi EC16. J. Bacteriol. 172: 5803-5815.

Darrasse A., Priou S., Kotoujansky A., Bertheau Y. (1994) PCR and restriction fragment length polymorphism of a pel gene as a tool to identify Erwinia carotovora in relation to potato diseases. Appl. Environ. Microbiol. 60: 1437-1443.

Degefu Y., Potrykus M., Golanowska M., Virtanen E., Łojkowska E. (2013) A new clade of Dickeya spp. plays a major role in potato blackleg outbreaks in North Finland. Ann. App. Biol. 162: 231-241.

Dellagi A., Rigault M., Segond D., Roux C., Kraepiel Y., Cellier F., Briat J.F., Gaymard F., Expert D. (2005) Siderophoremediated upregulation of Arabidopsis ferritin expression in response to Erwinia chrysanthemi infection. Plant J. 43: 262-272.

Delepelaire P., Wandersman C. (1989) Protease secretion by Erwinia chrysanthemi. Proteases $B$ and $C$ are synthesized and secreted as zymogens without a signal peptide. J. Biol. Chem. 264: 9083-9089.

Delepelaire P., Wandersman C. (1990) Protein secretion in Gram-negative bacteria. The extracellular metalloprotease
$B$ from Erwinia chrysanthemi contains a C-terminal secretion signal analogous to that of Escherichia coli alphahemolysin. J. Biol. Chem. 265: 17118-17125.

Elphinstone J. (1987) Soft Rot and Blackleg of Potato. Technical Information Bulletin 21, International Potato Center.

English G., Byron O., Cianfanelli F.R., Prescott A., Coulthurst S. (2014) Biochemical analysis of $T_{s s} K$, a core component of the bacterial Type VI secretion system, reveals distinct oligomeric states of TssK and identifies a TssK-TssFG subcomplex. Biochem. J. 461: 291-304.

Franza T., Mahe B., Expert D. (2005) Erwinia chrysanthemi requires a second iron transport route dependent on the siderophore achromobactin for extracellular growth and plant infection. Mol. Microbiol. 55: 261-275.

Franza T., Expert D. (2013) Role of iron homeostasis in the virulence of phytopathogenic bacteria: an 'a la carte' menu. Mol. Plant Pathol. 14: 429-438.

Gao B., Gupta R.S. (2012) Phylogenetic framework and molecular signatures for the main clades of the phylum Actinobacteria. Microbiol. Mol. Biol Rev. 76: 66-112.

Gardan L., Gouy C.., Christen R., Samson R. (2003) Elevation of three subspecies of Pectobacterium carotovorum to species level: Pectobacterium atrosepticum sp. nov., Pectobacterium betavasculorum sp. nov. and Pectobacterium wasabiae sp. nov. Int. J. Syst. Evol. Microbiol. 53: 381-391.

Garlant L., Koskinen P., Rouhiainen L., Laine P., Paulin L., Auvinen P., Holm L., Pirhonen M. (2013) Genome sequence of Dickeya solani, a new soft rot pathogen of potato, suggests its emergence may be related to a novel combination of non-ribosomal peptide/polyketide synthetase clusters. Diversity 5: 824-842.

Ghigo J.M., Wandersman C. (1992) Cloning, nucleotide sequence and characterization of the gene encoding the Erwinia chrysanthemi B374 PrtA metalloprotease: a third metalloprotease secreted via a C-terminal secretion signal. Mol. Gen. Genet. 236: 135-144.

Glasner J.D., Yang C.H., Reverchon S., Hugouvieux-CottePattat N., Condemine G., Bohin J.P., Van Gijsegem F., Yang S., Franza T., Expert D. et al. (2011) Genome sequence of the plant-pathogenic bacterium Dickeya dadantii 3937. J. Bacteriol. 193: 2076-2077.

Golanowska M., Galardini M., Bazzicalupo M., HugouvieuxCotte-Pattat N., Mengoni A., Potrykus M., Sławiak M., Łojkowska E. (2015) Draft genome sequence of a highly virulent strain of the plant pathogen Dickeya solani, IFB0099. Gen. Announ. 3(2): e00109-115.

Grenier A.M., Duport G., Pagès S., Condemine G., Rahbé Y. (2006) The phytopathogen Dickeya dadantii (Erwinia chrysanthemi 3937) is a pathogen of the pea aphid. Appl. Environ. Microbiol. 72: 1956-1965.

Grijpstra J., Arenas J., Rutten L.,Tommassen J. (2013) Autotransporter secretion: varying on a theme. Res. Microbiol. 164: 562-582.

Gupta R.S. (2010) Applications of conserved indels for understanding microbial phylogeny. [in:] Molecular Phylogeny of Microorganisms. Ed. A. Oren, R.T. Papke. Norwich: Caister Academic Press: 135-150. 
Hauben L., Moore E.R.B., Vauterin L., Steenackers M., Mergaert J., et al. (1998) Phylogenetic position of phytopathogens within the Enterobacteriaceae. Syst. Appl. Microbiol. 21: 384-397.

Hélias V., Hamon P., Huchet E., van der Wolf J.M., Andrivon D. (2012) Two new effective semiselective crystal violet pectate media for isolation of Pectobacterium and Dickeya. Plant Pathol. 61: 339-345.

Heilbronn J., Lyon, G.D. (1990) The ineffectuality of potato protease inhibitor on the extracellular protease from $\mathrm{Er}$ winia carotovora subsp. carotovora. J. App. Bacteriol. 69: 25-29.

Holeva M.C., Bell K.S., Hyman L.J., Avrova A.O., Whisson S.C., Birch P.R.J., Toth I.K., (2004) Use of a pooled transposon mutation grid to demonstrate roles in disease development for Erwinia carotovora subsp. atroseptica putative type III secreted effector (DspE/A) and helper $(H r p N)$ proteins. Mol. Plant Microbe Inter. 17: 943-950.

Hommais F., Oger-Desfeux C., Van Gijsegem F., Castang S., Ligori S., Expert D., Nasser W., Reverchon S. (2008) $P e c S$ is a global regulator of the symptomatic phase in the phytopathogenic bacterium Erwinia chrysanthemi 3937. J. Bacteriol. 190: 7508-7522.

Hugouvieux-Cotte-Pattat N., Condemine G., Nasser W., Reverchon R. (1996) Regulation of pectinolysis in Erwinia chrysanthemi. Ann. Rev. Microbiol. 50: 213-257.

Hugouvieux-Cotte-Pattat N., Condemine G., Shevchik V.E. (2014) Bacterial pectate lyases, structural and functional diversity. Environ. Microbial. Rep. 6: 427-440.

Jafra S., Figura I., Hugouvieux-Cotte-Pattat N., Łojkowska E. (1999) Expression of Erwinia chrysanthemi pectinase genes pelI, pelL, and pelZ during infection of potato tubers. Mol. Plant-Microbe Inter. 12: 845-851.

Khayi S., Mondy S., Beury-Cirou A., Moumni M., Hélias V., Faure D. (2014) Genome sequence of the emerging plant pathogen Dickeya solani strain RNS 08.23. 3.1 A. Gen. Announ. 2: 1270-1273.

Kim H.S., Thammarat P., Lommel S.A., Hogan C.S., Charkowski A.O. (2011) Pectobacterium carotovorum elicits plant cell death with DspE/F, but does not suppress callose or induce expression of plant genes early in plant-microbe interactions. Mol. Plant Microbe Inter. 24: 773-786.

Kotoujansky A., Lemattre M., Boistard P. (1982) Utilization of a thermosensitive episome bearing transposon TN10 to isolate Hfr donor strains of Erwinia carotovora subsp. chrysanthemi. J. Bacteriol. 150: 122-131.

Kyöstiö S.R.M., Cramer C.L., Lacy, G.H. (1991) Erwinia carotovora subsp. carotovora extracellular protease: characterisation and nucleotide sequence of the gene. J. Bacteriol. 173: 6537-6546.

Laurila J., Ahola V., Lehtinen A., Joutsjoki T., Hannukkala A., Rahkonen A., Pirhonen M. (2008) Characterization of Dickeya strains isolated from potato and river water samples in Finland. Eur. J. Plant Pathol. 122: 213-225.

Laurilla J., Hannukkala A., Nykyri J., Pasanen M., Hélias V., Garlant L., Pirhonen M. (2010) Symptoms and yield re- duction caused by Dickeya spp. strains isolated from potato and river water in Finland. Eur. J. Plant Pathol. 126: 249-262.

Lee Y.A., Yu C.P. (2005) A differential medium for the isolation and rapid identification of a plant soft rot pathogen, Erwinia chrysanthemi. J. Microbiol. Meth. 64: 200-206.

Lelliott R.A., Dickey R.S. (1984) Genus VII. Erwinia. Bergey's Man. System. Bacteriol. 1: 469-476.

Leo J.C., Grin I., Linke D. (2012) Type V secretion: mechanism(s) of autotransport through the bacterial outer membrane. Philos. Trans. R. Soc. Lond. B 367: 1088-1101.

Lerat E., Daubin V., Ochman H., Moran N.A. (2005) Evolutionary origins of genomic repertoires in bacteria. PLoS Biol. 3(5): e130.

Letoffe S., Delepelaire P., Wandersman C. (1989) Characterization of a protein inhibitor of extracellular proteases produced by Erwinia chrysanthemi. Mol. Microbiol. 3: 79-86.

Letoffe S., Delepelaire P., Wandersman C. (1990) Protease secretion by Erwinia chrysanthemi: the specific secretion functions are analogous to those of Escherichia coli alphahaemolysin. EMBO J. 9: 1375.

Linhartova I., Bumba L, Masın J., Basler M., Osicka R., et al. (2010) RTX proteins: a highly diverse family secreted by a common mechanism. FEMS Microbiol. Rev. 34: 1076-1012.

Liu H., Coulthurst S.J., Pritchard L., Hedley P.E., Ravensdale M., et al. (2008) Quorum sensing coordinates brute force and stealth modes of infection in the plant pathogen Pectobacterium atrosepticum. PloS Pathogens 20: e1000093.

Łojkowska E., Masclaux C., Boccara M., Robert-Baudouy J., Hugouvieux-Cotte- Pattat N. (1995) Characterization of the pell gene encoding a novel pectate lyase of Erwinia chrysanthemi 3937. Mol. Microbiol. 16: 1183-1195.

Łojkowska E., Potrykus M., Sławiak M. (2010) Molecular characterization and pathogenicity of Dickeya strains isolated recently from potato plants in Poland. [in:] Proceedings of the 12th International Conference on Plant Pathogenic Bacteria, 7-11 June 2010, St. Denis, Reunion, 158.

Ma B., Hibbing M.E., Kim H.S., Reedy R.M., Yedidia I., et al. (2007) Host range and molecular phylogenies of the soft rot enterobacterial genera Pectobacterium and Dickeya. Phytopathology 97: 1150-1163.

Mansfield J., Genin S., Magori S., Citovsky V., Sriariyanum M., Ronald P., Dow M., Verdier V., Beer S.V., Machado M.A., Toth I., Salmond G., Foster G.D. (2012) Top 10 plant pathogenic bacteria in molecular plant pathology. Mol. Plant Pathol. 13: 614-629.

Marits R., Tshuikina M., Pirhonen M., Laasik E., Mae A. (2002) Regulation of the expression of prtW::gusA fusions in Erwinia carotovora subsp. carotovora. Microbiology 148: 835-842.

Mattinen L., Somervuo P., Nykyri J., Nissinen R., Kouvonen P., Corthals G., Auvinen P., Aittamaa M., Valkonen J.P., Pirhonen M. (2008) Microarray profiling of host-extractinduced genes and characterization of the type VI secretion cluster in the potato pathogen Pectobacterium atrosepticum. Microbiology 154: 2387-2396. 
McMillan G.P., Barrett A.M., Perombelon M.C.M. (1994) An isoelectric focusing study of the effect of methyl esterified pectic substances on the production of extracellular pectin isoenzymes by soft rot Erwinia spp. J. App. Bacteriol. 77: $175-184$.

Mhedbi-Hajri N., Malfatti P., Pedron J., Gaubert S., Reverchon S., Van Gijsegem F. (2011) PecS is an important player in the regulatory network governing the coordinated expression of virulence genes during the interaction between Dickeya dadantii 3937 and plants. Environ. Microbiol. 13: 2901-2914.

Nasser W., Reverchon S., Vedel R., Boccara M. (2005) PecS and PecT corregulate the synthesis of HrpN and pectate lyases, two virulence determinants in Erwinia chrysanthemi 3937. Mol. Plant Microbe Inter. 18: 1205-1214.

Nasser W., Dorel C., Wawrzyniak J., Van Gijsegem F., Groleau M.C., Déziel E., Reverchon S. (2013) Vfm a new quorum sensing system controls the virulence of Dickeya dadantii. Environ. Microbiol. 15: 865-880.

Nguyen H.A., Kaneko J., Kamio Y. (2002) Temperature-dependent production of carotovoricin Er and pectin lyase in phytopathogenic Erwinia carotovora subsp. carotovora Er. Biosci. Biotech. Biochem. 66: 444-447.

Nykyri J., Niemi O., Koskinen P., Nokso-Koivisto J., Pasanen M., et al. (2012) Revised phylogeny and novel horizontally acquired virulence determinants of the model soft rot phytopathogen Pectobacterium wasabiae SCC3193. PLoS Pathog. 8(11): e1003013.

Nykyri J., Fang X., Dorati F., Bakr R., Pasanen M., Niemi O., Pirhonen M. (2014) Evidence that nematodes may vector the soft rot causing enterobacterial phytopathogens. Plant Pathol. 63: 747-757.

Palacio-Bielsa A., Cambra M.A., López M.M. (2006) Characterisation of potato isolates of Dickeya chrysanthemi in Spain by a microtitre system for biovar determination. Ann. App. Biol. 148: 157-164.

Parkinson N., DeVos P., Pirhonen M., Elphinstone J. (2014) Dickeya aquatica sp. nov., isolated from waterways. Inter. J. System. Evol. Microbiol. 64: 2264-2266.

Parkinson N., Pritchard L., Bryant R., Toth I., Elphinstone J. (2015) Epidemiology of Dickeya dianthicola and Dickeya solani in ornamental hosts and potato studied using variable number tandem repeat analysis. Eur. J. Plant Pathol. 141: 63-70.

Pédron J., Mondy S., des Essarts Y. R., Van Gijsegem F., Faure D. (2014) Genomic and metabolic comparison with Dickeya dadantii 3937 reveals the emerging Dickeya solani potato pathogen to display distinctive metabolic activities and T5SS/T6SS-related toxin repertoire. BMC Genomics 15: 283.

Perombelon M.C.M., Kelman A. (1980) Ecology of the soft rot erwinias. Annu. Rev. Phytopathol. 18: 361-387.

Perombelon M.C.M. (2002) Potato diseases caused by soft rot erwinias: an overview of pathogenesis. Plant Pathol. 51: 1-12.

Potrykus M., Golanowska M., Hugouvieux-Cotte-Pattat N., Łojkowska E. (2014a) Regulators involved in Dickeya so- lani virulence, genetic conservation, and functional variability. Mol. Plant Microbe Inter. 27: 700-711.

Potrykus M., Śledź W., Golanowska M., Sławiak M., Binek A., Motyka A., Żołędowska S., Czajkowski R., Łojkowska E. (2014b) Simultaneous detection of major blackleg and soft rot bacterial pathogens in potato by multiplex polymerase chain reaction. Ann. App. Biol. 165: 474-487.

Potrykus M., Golanowska M., Śledź W., Żołędowska S., Motyka A., Kołodziejska A., Butrymowicz J., Łojkowska E. (2016) Biodiversity of Dickeya spp. isolated from potato plants and water sources in temperate climate. Plant Dis. 100: 408-417.

Praillet T., Reverchon S., Nasser W. (1997) Mutual control of the PecS/PecM couple, two proteins regulating virulence factor synthesis in Erwinia chrysanthemi. Mol. Microbiol. 24: 803-814.

Pritchard L., Humphris S., Saddler G., Parkinson N.M., Bertrand V., Elphinstone J., Toth I. (2012) Detection of phytopathogens of the genus Dickeya using PCR primer prediction pipeline for draft bacterial genome sequences. Plant Pathol. 62: 587-596.

Pritchard L., Humphris S., Baeyen S., Maes M., Van Vaerenbergh J., Elphinstone J., Saddler G., Toth I. (2013a) Draft genome sequences of four Dickeya dianthicola and four Dickeya solani strains. Genome Announ. 1: 4.

Pritchard L., Humphris S., Saddler G., Elphinstone J.G., Pirhonen M., Toth I.K. (2013b) Draft genome sequences of 17 isolates of the plant pathogenic bacterium Dickeya. Gen. Announ. 1: e00978-01013.

Pritchard L., Glover R.H., Humphris S., Elphinstone J.G., Toth I.K. (2016) Genomics and taxonomy in diagnostics for food security: soft-rotting enterobacterial plant pathogens. Anal. Meth. 8: 12-24.

Py B., Isabelle B.G., Haiech J., Chippaux M., Barras F. (1991) Cellulase EGZ of Erwinia chrysanthemi: structural organization and importance of His98 and Glu133 residues for catalysis. Protein Engin. 4: 325-333.

Py B., Barras F., Harris S., Robson N., Salmond G.P.C. (1998) Extracellular enzymes and their role in Erwinia virulence. [in:] Bacterial Pathogenesis: Methods in Microbiology. Ed. P. Williams, J. Ketley, G. Salmond, London, UK: Academic Press Ltd, 27: 157-168.

Reverchon S., Rouanet C., Expert D., Nasser W. (2002) Characterization of indigoidine biosynthetic genes in Erwinia chrysanthemi and role of this blue pigment in pathogenicity. J. Bacteriol. 184: 654-665.

Reverchon S., Nasser W. (2013) Dickeya ecology, environment sensing and regulation of virulence programme. Environ. Microbiol. Rep. 5: 622-636.

Ribot E.M., Fitzgerald C., Kubota K., Swaminathan B., Barrett T.J. (2001) Rapid pulsed-field gel electrophoresis protocol for subtyping of Campylobacter jejuni. J. Clin. Microbiol. 39: 1889-1894.

Rojas C.M., Ham J.H., Deng W.-L., Doyle J.J., Collmer A. (2002) HecA, a member of a class of adhesins produced by diverse pathogenic bacteria, contributes to the attachment, aggregation, epidermal cell killing, and virulence 
phenotypes of Erwinia chrysanthemi EC16 on Nicotiana clevelandii seedlings. Proc. Natl. Acad. Sci. USA 99: 13142-13147.

Rouanet C., Reverchon S., Rodionov D.A., Nasser W. (2004) Definition of a consensus DNA-binding site for PecS, a global regulator of virulence gene expression in Erwinia chrysanthemi and identification of new members of the PecS regulon. J. Biol. Chem. 279: 30158-30167.

RPD - Report on plant disease, Department of Crop Sciences, University of Illinois at Urbana-Champaign, RPD No. 943 July 1990.

Ruhe Z.C., Low D.A., Hayes C.S. (2013) Bacterial contactdependent growth inhibition. Trends Microbiol. 21: 230237.

Russell A.B., Singh P., Brittnacher M., Bui N.K., Hood R.D., Carl M.A., Agnello D.M., Schwarz S., Goodlett D.R., Vollmer W., Mougous J.D. (2012) A widespread bacterial type VI secretion effector superfamily identified using a heuristic approach. Cell Host Microb. 11: 538-549.

Salmond G.P.C. (1994) Secretion of extracellular virulence factors by plant pathogenic bacteria. Annu. Rev. Phytopathol. 32: 181-200.

Samson R., Poutier F., Sailly M., Jouan B. (1987) Caractérisation des Erwinia chrysanthemi isolées de Solanum tuberosum et d'autres plantes-hôtes selon les biovars et sérogroupes. EPPO Bulletin 17: 11-16.

Samson R., Legendre J.B., Christen R., Saux M.F.L., Achouak W., Gardan L. (2005) Transfer of Pectobacterium chrysanthemi (Burkholder et al. 1953) Brenner et al. 1973 and Brenneria paradisiaca to the genus Dickeya gen. nov. As Dickeya chrysanthemi comb. nov. and Dickeya paradisiaca comb. nov. And delineation of four novel species, Dickeya dadantii sp. nov., Dickeya dianthicola sp. nov., Dickeya dieffenbachiae sp. nov. and Dickeya zeae sp. Inter. J. System. Evol. Microbiol. 55: 1415-1427.

Schauer K., Rodionov D.A, de Reuse H. (2008) New substrates for TonB-dependent transport: Do we only see the "tip of the iceberg?"Trends Biochem. Sci. 33: 330-338.

Sławiak M., Łojkowska E., van der Wolf (2009a) First report of bacterial soft rot on potato caused by Dickeya spp. (syn. Erwinia chrysanthemi) in Poland. Plant Pathol. 58: 794.

Sławiak M., van Beckhoven J.R.C.M., Speksnijder A.G.C.L., Czajkowski R., Grabe G., van der Wolf J.M. (2009b) Biochemical and genetic analysis reveal a new clade of biovar 3 Dickeya spp. strains isolated from potato in Europe. Eur. J. Plant Pathol. 125: 245-261.

Surgey N., Robert-Baudouy J., Condemine G. (1996) The Erwinia chrysanthemi pecT gene regulates pectinase gene expression. J. Bacteriol. 178: 1593-1599.

Thomson N.R., Thomas J.D., Salmond G.P. (1999) 12 Virulence Determinants in the Bacterial Phytopathogen Erwinia. Gen. Meth. Diver. Prokaryotes 29: 347.

Toth I.K., Bell K.S., Holeva M.C., Birch P.R. (2003) Soft rot erwiniae: from genes to genomes. Mol. Plant Pathol. 4: 17-30.
Toth I.K., Pritchard L., Birch P.R. (2006) Comparative genomics reveals what makes an enterobacterial plant pathogen. Annu. Rev. Phytopathol. 44: 305-336.

Toth I.K., van der Wolf J.M., Saddler G., Łojkowska E., Hélias V., Pirhonen M., Tsror (Lahkim) L., Elphinstone J.G. (2011) Dickeya species: an emerging problem for potato production in Europe. Plant Pathol. 60: 385-399.

Tsor (Lahkim) L., Erlich O., Lebiush S., Hazanovsky M., Zig U. (2009) Assessment of recent outbreaks of Dickeya sp. (syn. Erwinia chrysanthemi) slow wilt in potato crops in Israel. Eur. J. Plant Pathol. 123: 311-320.

Tsror (Lahkim) L., Ben-Daniel B., Chalupowicz L., van der Wolf J., Lebiush S., Erlich O., Dror O., Barel V., Nijhuis E., Manulis-Sasson S. (2013) Characterization of Dickeya strains isolated from potato grown under hot-climate conditions. Plant Pathol. 62: 1097-1105.

van der Wolf J.M., de Haas B.H., van Hoof R., de Haan E.G., van den Bovenkamp G.W. (2014a) Development and evaluation of Taqman assays for the differentiation of Dickeya (sub)species. Eur. J. Plant Pathol.138: 695-709.

van der Wolf J.M., Nijhuis E.H., Kowalewska M.J., Saddler G.S., Parkinson N., Elphinstone J.G., Pritchard L., Toth I.K., Łojkowska E., Potrykus M.,Waleron M. (2014b) Dickeya solani sp. nov., a pectinolytic plant pathogenic bacterium isolated from potato (Solanum tuberosum). Inter. J. System. Evol. Microbiol. 64: 768-774.

Van Vaerenbergh J., Baeyen S., De Vos P., Maes M. (2012) Sequence diversity in the Dickeya fliC gene: phylogeny of the Dickeya Genus and TaqMan (R) PCR for 'D. solani', new Biovar 3 variant on potato in Europe. PLoS One 7: e35738.

Versalovic J., Koeuth T., Lupski R. (1991) Distribution of repetitive DNA sequences in eubacteria and application to fingerprinting of bacterial genomes. Nuc. Acid Res. 19: 6823-6831.

Versalovic J., Schneider M., De Bruijn F.J., Lupski J.R. (1994) Genomic fingerprinting of bacteria using repetitive sequence-based polymerase chain reaction. Meth. Mol. Cell. Biol. 5: 25-40.

Waldee E.L. (1945) Comparative studies of some peritrichous - phytopathogenic bacteria. Iowa State Coll. J. 19: 435484.

Waleron M., Waleron K., Podhajska A.J., Łojkowska E. (2002a) Genotyping of bacteria belonging to the former Erwinia genus by PCR-RFLP analysis of a recA gene treatment. Microbiology 148: 583-595.

Waleron M., Waleron K., Łojkowska E. (2002b) Genotypic characterisation of the Erwinia genus by PCR-RFLP analysis of rpoS Gene. Plant Prot. Scien. 38: 288-290.

Waleron M., Czajkowski R., Waleron K., Łojkowska E. (2013) Restriction fragment length polymorphism-based identification of 'Dickeya solani', a new genetic clade of Dickeya spp. J. Plant Pathol. 95: 609-613.

Weinert N., Meincke R., Gottwald C., Radl V., Dong X., Schloter M., Berg G., Smalla K. (2010) Effects of genetically modified potatoes with increased zeaxanthin content on 
the abundance and diversity of rhizobacteria with in vitro antagonistic activity do not exceed natural variability among cultivars. Plant Soil 326: 437-452.

Winslow C.E.A., Broadhurst J., Buchanan R.E., Krumwiede C., Rogers L.A., Smith G.H. (1917) The families and genera of the bacteria. Preliminary report of the Committee of the Society of American Bacteriologists: Characterization and Classification of Bacterial Types. J. Bacteriol. 2: 505566.

Whitney J.C., Chou S., Russell A.B., Biboy J., Gardiner T.E., Ferrin M. A., Brittnacher M., Vollmer W., Mougous J.D.
(2013) Identification, structure, and function of a novel type VIsecretion peptidoglycan glycoside hydrolase effector - immunity pair. J. Biol. Chem. 288: 26616-26624.

Zimnoch-Guzowska E., Łojkowska E. Perombelon M. (2005) Resistance in Potato to Bacterial Pathogens. [in:] Genetic Improvement of Solanaceous Crops. Vol. 1 Potato. Ed. M.K. Razdan and K. Mattoo. Science Publishers, Inc. Enfield, USA, Plymouth, UK 14: 339-395. 